Volume 2 Nomor 2 Desember 2017 hal 91-101

Avaliable online at: http://e-journal.unipma.ac.id/index.php/gulawentah

\title{
KOMODIFIKASI TUBUH PEREMPUAN OPERATOR SPBU 54.801.50
}

\author{
I Wayan Gede Lamopia ${ }^{1}$, Riza Wulandari ${ }^{2}$ \\ ${ }^{1,2)}$ Program Studi Sistem Informasi, STMIK STIKOM BALI \\ Email: ${ }^{1)}$ lamopia@yahoo.com; ${ }^{2)}$ rizawulandari@stikom-bali.ac.id
}

\begin{abstract}
Abstrak
Perempuan memiliki nilai tanda dan nilai tukar yang dapat direpresentasikan pada era kini.Perihal tubuh, perempuan menjadi objek yang berpotensi untuk dieksplotasi sebagai nilai ekonomis yang tinggi.Penelitian ini bertujuan untuk menggambarkan komodifikasi tubuh perempuan operator SPBU 54.801.50 di Denpasar.Pemilihan metode studi kasus dalam penelitian ini sangat tepat dikarenakan hanya SPBU 54.80.50 yang memperkerjakan perempuan sebagai operator dengan berpakaian seksi.Jenis penelitian kualitatif ini menggunakan teknik pengumpulan data berupa observasi, wawancara dan dokumentasi dan teknik analisis menggunakan model interaktif.Hasil dari penelitian ini adalah perempuan yang bekerja sebagai operator di SPBU 54.801.50cukup menerima apa yang telah ditetapkan oleh atasan untuk berpakaian seksi, adapun yang mempengaruhi memilih pekerjaan dengan ketentuan tersebut berasal dari faktor eksternal dan internal. Komodifikasi yang melekat pada perempuan operator tersebut dirasakan tidak berdampak pada pencitraan negative seorang perempuan.Hal itu dianggap sebagai bentuk strategi pemasaran dari para pemegang kekuasaan untuk mendapatkan hasil produksi yang diinginkan.
\end{abstract}

Kata kunci: Operator Perempuan; SPBU; Komodifikasi Tubuh.

\section{Comodification of Women Operator SPBU 54.801.50}

\begin{abstract}
Women have a value exchange rate and signs that can be represented in the present era. About the body, women into objects which can potentially dieksplotasi as a high economic value. This research aims to describe how the commodification of women's bodies operator SPBU 54.801.50 in Denpasar. The selection of the method of case study in this research very precisely because the only SPBU 54.80.50 which employs women as operators dressed sexy. This type of qualitative research using data collection techniques in the form of observation, interview and documentation. The results of this research are women who work as SPBU operators in 54.801.50 simply accept what has been determined by superiors to dress sexy, as for affecting the provision of job choosing comes from factors external and internal. The commodification of women attached to the operator's perceived no impact on a woman's negative imagery. It is considered as a form of marketing strategies of power holders to obtain the desired production outcomes.

Keywords: Female Operators, Gas Stations, The Commodification Of The Body

\section{Pendahuluan}

Indonesia merupakan salah satu negara berkembang dimana globalisasi dan modernisasi terus menjalar masuk menggerogoti pilar bangsa secara

perlahan melalui sector ekonomi. Beberapa sector ekonomi yang saat ini merupakan symbol kapitalis pribumi adalah hadirnya produk moderniasi seperti Mcdonalisasi, Westernisasi,
\end{abstract}


gulawentah: Jurnal Studi Sosial

Volume 2 Nomor 2 Desember 2017 hal 91-101

Avaliable online at http://e-journal.unipma.ac.id/index.php/gulawentah

Amerikanisasi. Produk tersebut merambah kota besar yang ada di Indonesia dengan menyerang penduduk yang memiliki tingkat perekonomian yang cukup tinggi untuk memenuhi sebuah gaya hidup atau budaya kebaratan. Produk dari modernisasi dan globalisasi tidak hanya menyentuh sektor perekonomian yang dibuktikan dengan pudarnya interaksi pasar tradisional digantikan dengan hadirnya supermarket atau mall yang memenuhi kebutuhan hidup sehari-hari dikemas lebih efisien, cepat, tanpa harus melalui budaya tawar menawar seperti aktifitas di pasar tradisional pada umumnya(Pilliang,2006).

Masyarakat Indonesia dewasa ini tidak hanya terpengaruh pada sektor ekonomi dalam era globalisasi, namun dalam tatanan tindakan atau perilaku sudah mulai kentara pada perubahan gaya hidup. Gaya hidup (life style) yang kekinian mengarah kepada budaya barat dari segi fashion, cara berinteraksi, cara berkomunikasi dan lain-lain (Nanang Martono,2013). Perubahan gaya hidup menjadikan penganut arus modernisasi menjadi sebuah arena aktualisasi diri demin mendapatkan pengakuan diri atas apa yang telah dilakukan. Prestige adalah faktor dari adanya perubahan gaya hidup masyarakat Indonesia dewasa ini. Memaksakan suatu kehendak dengan mengedepankan keinginan yang tidak berdasar pada kebutuhan hingga akhirnya menjadikan konsumtif dalam segi pemenuhan kebutuhan.
Berbagai teori ekonomi yang dikembangkan di Barat pada umumnya memang bersifat elitis. Dalam kaitannya perekonomian, elitis merupakan segala bentuk tindakan yang banyak dilihat ari segi kaum elit dimana dalam revolusi perancis disebut kaum borjuis (Baudrillad,2009). Hal tersebut mengakibatkan setiap kemajuan ekonomi dilihat dari peran kaum elit dalam proses kemajuan, dan tidak pernah dinyatakan apa peran masyarakat grassroot di dalamnya. Dalam rumusan UndangUndang Dasar 1945 yang berbunyi perekonomian Indonesia disusun sebagai usaha bersama berdasar atas asas kekeluargaan. Negara menguasai bumi,air dan kekayaan alam sebagai pokok-pokok kemakmuran rakyat, dan cabang cabang produksi yang penting serta menguasai hajat kehidupan orang banyak dikuasai negara untuk sebesar-besarnya kemakmuran rakyat. Dalam hal tersebut ekonomi rakyat adalah landasan ekonomi nasional yang harus dilindungi da dikembangkan menuju ketahanan ekonomi nasional yang handal dan tangguh. Jauh sebelum kemerdekaan Ir. Soekarno yang tidak belajar ekonomi menunjukkan betapa sistem kapitalisme benar-benar menyengsarakan rakyat Indonesia.

Kenyataan yang saat ini terjadi, para penganut kapitalisme semakin kokoh kuat didukung oleh borjuisme yang seakan ingin menguasai kehidupan masyarakat kecil. Bahkan saat ini, 


\section{gulawentah: Jurnal Studi Sosial}

Volume 2 Nomor 2 Desember 2017 hal 91-101

Avaliable online at http://e-journal.unipma.ac.id/index.php/gulawentah

beberapa masyarakat yang memiliki skala perekonomian yang rendah rela menerima pekerjaan apapun sebatas pemenuhan kebutuhan hidup dan keinginan diri yang semakin tak terkendali. Realita saat ini yang terjadi banyak ditemukan worker yang tidak sesuai dengan bidangnya, tidak sesuai dengan ekspektasi, tidak sesuai dengan keahlian yang dimiliki terutama ditemukan pada masyarakat kelas menengah kebawah. Para generasi muda saat ini juga sudah mulai terjangkit pemenuhan masa depan dengan mencari pekerjaan yang tidak sesuai dengan bidang dan keahlian serta minat. Konsep patriarki dan matriarki pun saat ini sudah mulai bergeser dimana tidak ada perbedaan dalam kaitannya pemenuhan kebutuhan rumah tangga yakni siapa yang bekerja dan siapa yang berada di rumah.Seperti halnya yang saat ini ditemui adalah pegawai SPBU yang ada di salah satu Provinsi di Indonesia yaitu Bali.Ada hal yang menarik pada mata pencaharian pekerja perempuan yakni sebagai operator SPBU. Sudah banyak kita temukan di berbagai daerah tentang pekerjaan operator SPBU.Di Provinsi Bali, terdapat stasiun pengisian bahan bakar umum yang beroperasi di masingmasing Kota. Denpasar yang menjadi ibukota Provinsi Bali memiliki jumlah sekitar 42 SPBU yang tersebar di beberapa titik. SPBU tersebut biasanya dimiliki oleh para kontraktor Bali ataupun luar Bali bahkan pihak asing yang bekerja sama dengan pihak PT. Pertamina. Salah satu SPBU yang menarik di Kota Denpasar adalah SPBU yang berada di Jalan By. Pass Suwung Denpasar. Fenomena pegawai SPBU perempuan yang ada disana sangat menarik. Cara berpakaian yang melekat pada tubuh mereka tidak pada lazimnya operator SPBU dengan seragam merah-merah dengan grooming pakaian yang simple dan sopan. Perusahaan tersebut memiliki 120 karyawan perempuan dengan mengenakan kostum mini dress dan makeup sebagai pendukung fashion. Mereka tersebar di beberapa titik SPBU yang tersebar di Denpasar dengan masing masing titik terdapat 12 pegawai perempuan. Adapun penelitian lain untuk menguatkan penelitian ini yakni berasal dari Ani Supartiyah tentang Perempuan di era industrialisasi : Konstruksi Diri Operator SPBU di Surabaya. Penelitian tersebut menunjukkan bahwaKonstruksi diri operator perempuan SPBU di Surabaya dapat diketahui bahwa terdapat perbedaan konstruksi diri antara operator perempuan SPBU Sukolilo dan SPBU Kayoon. Perbedaan tersebut pada akhirnya menimbulkan dampak yang berbeda terhadap pelayanan yang diberikan kepada pelanggan.Penelitian tentang komodifikasi tubuh operator perempuan SPBU yang ada Denpasar memiliki ketertarikan untuk diteliti.Dalam hal ini, poin penting penelitian ini perlu dilakukan adalah yang Pertama belum pernah dilakukan penelitian tentang komodifikasi 


\section{gulawentah: Jurnal Studi Sosial}

Volume 2 Nomor 2 Desember 2017 hal 91-101

Avaliable online at http://e-journal.unipma.ac.id/index.php/gulawentah

perempuan dengan subjek perempuan operator SPBU. Kedua, penelitian ini menarik untuk dikaji karena operator SPBU di Denpasar cara melakukan kegiatan produktif dengan jalan bekerja berbeda dari segi fashionable. Di Stasiun Pengisian Bahan Bakar Umum di berbagai daerah memiliki standar operasional dalam hal mengenakan seragam kerja.Namun hal ini, hanya satusatunya SPBU yang ada di Denpasar tersebut seragam kerja yang dikenakan lebih menonjolkan tubuh. Tujuan dari penelitian ini adalah untuk mengetahui komodifikasi seperti apa yang terjadi pada operator perempuan SPBU di Denpasar.

\section{Metode Penelitian}

Dalam menentukan hipotesa penelitian harus menggunakan sebuah metode untuk memecahkan masalah yang akan di teliti. Metode dalam sebuah penelitian bertujuan sebagai konstruksi langkah-langkah dalam menemukan hipotesa.Penelitian komodifikasi tubuh operator perempuan SPBU ini menggunakan jenis penelitian kualitatif dengan metode studi kasus.

Penelitian kualitatif merupakan jenis penelitian yang mendeskripsikan sebuah permasalahan secara jelas dalam sebuah penelitian dengan menggunakan prosedur yang menghasilkan data deskriptif berupa kata-kata tertulis atau lisan dari orang-orang dan perilaku yang dapat diamati (Basrowi dan Suwandi,
2008 : 21). Laporannya berisi amatan dari berbagai kejadian dan kondisi di tempat penelitian. Tujuan akhir dari penelitian kualitatif adalah untuk memahami apa yang dipelajari dari perspektif itu sendiri dari sudut pandang kejadiannya itu sendiri. Jadi dalam hal ini, penelitian kualitatif merupakan pilihan yang tepat untuk menjelaskan segala seseuatu secara mendalam dan menyeluruh.

Menurut Robert K.Yin mengemukan definisi dari studi kasus adalah satu impuiri ,empiris, yang menyelidiki fenomena dalam konteks kehidupan nyata, bila mana batas-batas antara fenomena dan konteks tak tampak dengan tegas, dan dimana multi sumber bukti dimanfaatkan. Studi kasus lebih banyak berkutat dan atau berupaya menjawab pertanyaan-pertanyaan "How", (bagaimana) dan "Why" (mengapa), serta pada tingkatan tertentu juga menjawab pertanyaan “What”(apa/apakah), dalam kegiatan penelitian (Bungin, 2005). Dalam penelitian sosial data merupakan hal yang krusial yang harus dimiliki oleh seorang peneliti. Pengumpulan data penelitian dapat menggunakan beberapa teknik yakni melalui observasi, wawancara secara mendalam (depth interview) dan dokumentasi atau foto.

Teknik pemilihan informan yang tepat dalam melakukan penelitian kualitatif studi kasus ini adalah denganmenggunakan teknikpurposive, teknik ini dilakukan dengan cara 


\section{gulawentah: Jurnal Studi Sosial}

Volume 2 Nomor 2 Desember 2017 hal 91-101

Avaliable online at http://e-journal.unipma.ac.id/index.php/gulawentah

pemilihan subjek yang ada dalam posisi terbaik untuk memberikan informasi yang dibutuhkan (Silalahi, 2010 : 272). Jenis teknik purposive ini dapat mengetahui informasi dan permasalahan secara mendalam serta dapat dipercaya sebagai menjadi sumber data. Prosedur ini perlu mengidentifikasi karakteristik dan kemudian menemukan situasi atau individu yang menampilkan berbagai dimensi dari karaktersitik tersebut. Dalam penelitian ini terdapat 1 Informan PemilikSPBU PT. Pande Group, 6 Karyawan Perempuan dari SPBU diklasifikasikan berdasarkan usia dan lama bekerja.

Penyajian data dalam penelitian ini dengan menggunakan model interaktif (Interactive Mode of Analysis).Tahapan dalam menganalisa penelitian dengan menggunakan model interaktif ini yaitu Pengumpulan data, Reduksi Data, Penyajian Data dan Penarikan kesimpulan.Setelah data terkumpul dilakukan analisa melalui tiga komponen yaitu reduksi data, penyajian data, dan penarikan kesimpulan dengan verifikasinya. Keempat komponen ini saling berinteraksi dan berkaitan satu sama lain sehingga tidak dapat dipisahkan dari kegiatan pengumpulan data, oleh karenanya analisis data dapat dilakukan sebelum, selama dan setelah proses pengumpulan data di lapangan.

Perlu diketahui bahwa dalam melakukan penelitian tidak hanya membutuhkan metode untuk mendapatkan hipotesa dari permasalahan yang dikaji. Ada hal yang harus diperhatikan bahwa dalam penentuan hipotesa tersebut dibutuhkan teori untuk mengasah permasalahan dengan berpacu pada konstruksi pemikiran para ahli. Penelitian ini memilih teoriDalam pemahaman tentang pemikiran seksualitas dan tubuh, Michel Foucault adalah suatu komodifikasi luar dari gagasan kekuasaan Karl Marx. Banyak orang yang menggemari teori Karl Marx dimana Michel Foucault membelot dari kultur tersebut. Michel menyukai gagasangagasan Nietzsche. Gagasan tentang kehendak untuk berkuasa dan genalogi moral akan ia turunkan menjadi teori pengetahuan atau kekuasaan. Foucault mengkonstruksikan idenya tentang kekuasaan dengan berbagai versi sudu pandang dan berbagai macam kepentingan.Ide kekuasaan Foucault bekerja seabgai pemerintahan dan peranperannya, seabgai kelas sosial yang berkuasa, sebagai tata laksana kapitalisme atau sebagai lembaga biasa yang tersebar di masyarakat yang mempengaruhi kehidupan manusia setiap hari.Pemikiran Foucault dapat diasumsikan bahwa ide pokok pemikiranya dilatarbelakangi oleh permenungan yang mendalam tentang kekuasaan-kekuasaan jahat yang muncul akibat perilaku ekonomi dan perilaku pengetahuan masyarakat Dunia (Ritzer,2010).

Dominasi kekuasaan dapat dilihat atas tema seksualitas.Foucault melihat 


\section{gulawentah: Jurnal Studi Sosial}

Volume 2 Nomor 2 Desember 2017 hal 91-101

Avaliable online at http://e-journal.unipma.ac.id/index.php/gulawentah

seksualitas sebagai pemahaman tentang kekuasaan. Bagaimana seksualitas sebagai pengalihan pemahaman tentang kekuasaan. Dalam hal kekuasaan pasti terdapat pertanyaan kenapa moralitas harus dibongkar, karena ada yang membentuk moralitas itu menjadi sekedar norma-norma baik-buruk, benar dan salah sehingga yang sangat mendesak sebelum pembahasan terkait moralitas Foucault mempersoalkan bagaimana, mengapa, dan untuk apa terjadi pelembagaan seperti itu. Kritisme moral yang hadir ditengah masyarakat tidak terlepas dari relativitas dimana sebuah norma yang tidak bisa berlaku universal, disemua tempat , disetiap tempat. Norma adalah bentukan yang selalu mengalami perkembangan, sementara itu masyarakat yang menerapkan norma dan kaidah kaida moral selalu berbeda sehingga tidak bisa diatur dengan model yang sama. Konstruksi pemikiran Foucault tentang seksualitas tidak selamanya tentang hal yang negativisti.Doktrin terhadap seksualitas merupakan lahan untuk mempersoalkan bagaimana kekuasaan itu berlangsung.Praktek yang paling konkrit dalam menjalankan kekuasaan. (M.Foucault, 2002 :102)

\section{Hasil Penelitian dan Pembahasan}

Stasiun Pengisian Bahan Bakar adalah tempat dimana kendaraan bermotor bisa memperoleh bahan bakar. Di Indonesia Stasiun Pengisian Bahan Bakar dikenal dengan nama SPBU
(Stasiun Pengisian Bahan Bakar Umum). Adapun penilaian dari masyarakat dari beberapa yang menyebut SPBU sebagai Pom Bensin atau singkatan dari Pompa Bensin.Stasiun Pengisian Bahan Bakar pada umumnya menyediakan beberapa jenis bahan bakar seperti bensin dan beberapa varian produk bensin, solar, $L P G$, dan terkadang minyak tanah.Di berbagai daerah Banyak Stasiun Pengisian Bahan Bakar yang juga menyediakan layanan tambahan. Misalnya Mushola, Anjungan Tunai Mandiri (ATM), pompa angina, toilet dan sebagainya. Pada SPBU yang menggunakan konsep modern, biasanya dilengkapi juga dengan minimarket, ATM, dan coffeshop sebagai arena untuk istirahat.

Di Indonesia, Stasiun Pengisian Bahan Bakar dijaga oleh petugas-petugas yang mengisikan bahan bakar kepada pelanggan. Pelanggan tersebut kemudian membayarkan biaya pengisian kepada petugas bahan bakar.Dalam menghadapi persaingan, Pertamina akhir-akhir ini telah meremajakan stasiun-stasiunnya misalnya dengan perubahan penampilan dan penambahan fasilitas.Selain itu, mereka juga lebih banyak membuka stasiun milik mereka sendiri dengan siste waralaba.Stasiun-stasiun tersebut umumnya lebih besar daripada stasiunstasiun waralaba (PT. Pertamina, 2004).Pihak pertamina memiliki strategi perusahaan dengan memfokusan pada usaha inti di bidang minyak, gas dan 


\section{gulawentah: Jurnal Studi Sosial}

Volume 2 Nomor 2 Desember 2017 hal 91-101

Avaliable online at http://e-journal.unipma.ac.id/index.php/gulawentah

bahan bakar. Pertamina juga berkomitmen untuk menerapkan prinsipprinsip tata kelola korporasi setara dengan perusahaan publik, memperkerjakan sumber daya manusia terbaik di bidangnya baik dalam maupun luar negeri, membangun bisnis sehat bersama mitra bisnis yang professional, terpercaya dan integitas.

SPBU 54.801.50 yang ada di Denpasar memiliki sebuah ketertarikan yang tidak biasa.Para pelaku ekonom yang dijadikan sebagai alat pemenuhan kebutuhan masyarakat yaitu operator SPBU memiliki karyawan perempuan. Umumnya, SPBU yang memperkerjakan perempuan sebagai operator harus menyesuaikan standar operasional perusahaan mulai dari Grooming sampai pada aturan dalam berpakaian. Di SPBU tersebut, keunikan yang terjadi adalah para pekerja operator SPBU perempuan tidak mengenakan seragam pada umumnya.Mereka mengenakan pakaian seksi seperti seorang Sales Promotion Girl. Perempuan yang bekerja di SPBU tersebut terlihat mengenakan pakaian yang tidak sesuai dengan operator SPBU pada umumnya. Pada penelitian yang telah dilakukan, terlihat operator perempuan SPBU hanya bekerja pada shift pagi yaitu dari jam 07.00-17.00 WITA, kemudian selanjutnya shift sore sampe malam yang bertugas menjadi operator SPBU adalah karyawan lakilaki.Para pekerja operator SPBU 54.801.50 di Denpasar berada dibawah naungan perusahaan PT. Pande Group. Perusahaan ini memiliki Stasiun Pengisian Bahan Bakar Umum tidak hanya pada satu tempat, diantaranya terletak di Jalan Pulau Kawe, di Jalan By Pass Ngurah Rai dan di tempat lainnya. Para pekerja operator perempuan SPBU yang mengenakan seragam seksi dapat dilihat pada Gambar 1 Operator Perempuan SPB. 
gulawentah: Jurnal Studi Sosial

Volume 2 Nomor 2 Desember 2017 hal 91-101

Avaliable online at http://e-journal.unipma.ac.id/index.php/gulawentah

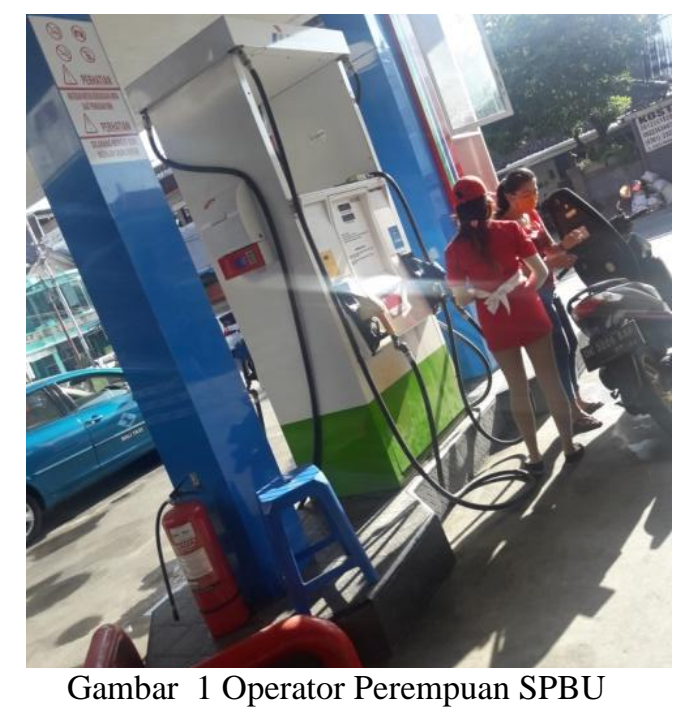

Standar yang ada pada operator SPBU adalah dengan mengenakan pakaian seragam atas menggunakan kemeja pendek bagi yang tidak berjilbab, dan panjang bagi yang berjilbab serta mengenakan celana panjang ditambahkan topi berwarna merah. Standar ini sudah ditemukan di berbagai tempat pengisian bahan bakar umum yang memperkerjakan perempuan sebagai operator.Hal ini memicu adanya sebuah bentuk komodifikasi tubuh yang terjadi pada operator perempuan di SPBU tersebut.

Komodifikasi muncul dikenalkan oleh para ilmuwan sosial yang merepresentasikan beberapa kajian tertentu sesuai konstruksi pemikirannya. Komodifikasi sebagai cara kapitalis melancarkan tujuannya untuk mengakumulasi capital atau menyadari transformasi nilai guna menjadi nilai tukar. Komoditas dan komodiikasi merupakan dua hal yang memiliki relasi objek dan proses dan menjadi salah satu indicator kapitalisme global yang saat ini telah terjadi. Dalam dunia ekonomi, komodifikasi merupakan salah satu bentuk strategi penguasaan pemasaran selain strukturasi dan spasialisasi. Menurut Vincent Mosco potret cara kapitalisme dengan membawa akumulasi tujuan kapitalnya atau mudahnya dapat digambarkan sebagai sebuah perubahan nilai fungsi atau guna menjadi sebuah nilai tukar.Sekarang ini banyak bentuk komodifikasi yang muncul dalam prkembangan kehidupan manusia karena banyak yang dijadikan komoditas oleh manusia (Machyudin Agung, 2013 : 8).

$$
\text { Mosco juga menjelaskan }
$$
komodifikasi adalah transformasi nilai guna menjadi nilai tukar yang nantinya menjadi entry process untuk memahami fennomenia media yang ada dimanai dari perspektif ekonomi politik kritis. (Santi Indra Astuti, 2005 :23). Adapun bentukbentuk komodifikasi jika dihubungkan dengan teori hipersemiotika dapat dikategorikan menjadi 3 jenis, yaitu : 


\section{gulawentah: Jurnal Studi Sosial}

\section{Volume 2 Nomor 2 Desember 2017 hal 91-101}

Avaliable online at http://e-journal.unipma.ac.id/index.php/gulawentah

1. Tanda daur ulang, merupakan tanda yang telah digunakan untuk menjelaskan peristiwa-peristiwa masa lalu dengan konteks ruang, waktu dan tempat yang khas. Hal tersebut digunakan untuk menjelaskan peristiwa saat ini yang sesungguhnya berbeda atau tidak ada sama sekali.

2. Tanda artifisal merupakan tanada yang direkayasa elalui teknologi pencitraan seperti teknologi digital, simulasi dan komputer grafis yang tidak memiliki referensi pada realitas.

3. Tana ekstrim merupakan tanda yang ditampilkan dalam sebuah model pertandaan yang ekstrim khususnya melalui efek efek modulasi pertandaan dan makna yang jauh lebih besar dengan apa yang ada pada realitas.

Komodifikasi dikritisi oleh Adorno dimana hal tersebut terjadi karena hasil dari perkembangan industri budaya.Produksi benda budaya pada zaman pra industri diproduksi secara murni tidak ada campur tagan dengan system pasar dan produksinya. Namun pada era globalisasi sistem kapitalisme memunculkan ledakan kebudayaan pada segala aspek kehidupan sehingga memunculkan kebutuhan massa. Industri telah memproduksi berbagai artefak kebudayaan yang terjadi menjadi kebutuhan massa dan menjadi faktor penentu dalam proses produksinya. Marx memberikan makna komodifikasi sebagai apapun yang diproduksi dan untuk diperjualbelikan.Tidak ada nilai guna murni yang dihasilkan namun hanya nilai jual untuk diperjual belikan. Komodifikasi menggambarkan proses dimana sesuatu tidak yang memiliki nilai ekonomis diberikan nilai dan karenanya bagaimana pasar dapat menggantikan nilai-nilai sosial lainnya (Evan,2004 :16).

Era modern saat ini terjadi banyak perempuan yang dijadikan sebagai komoditas atas kepentingan pribadi maupun khalayak umum.Perempuan memiliki peran yang multifungsi dalam kehidupan rumah tangga maupun berkehidupan bermasyarakat, perempuan mampu menjalankan perannya sesuai dengan kondisi sekitar.Kemajuan budaya menjadikan konstruksi perempuan feminis memudar seiring berjalannya waktu.Para kaum feminis tersebut pada zaman dahulu menjalankan perannya sebagai perempuan rumahan yang melakukan pekerjaan seperti memasak, membersihkan rumah dan mengurus keperluan rumah tangga.Namun, seiring berkembangnya jaman perempuan sudah mulai masuk ke ranah maskulin dalam bingkai perempuan.Konsep emansipasi bagi perempuan cukup memberikan perubahan besar bagi mereka.Salah satunya adalah perempuan operator di SPBU Denpasar.Himpitan ekonomi dan pengaruh budaya modern merupakan faktor pendukung para perempuan yang memilih bekerja sebagai operator SPBU 54.801.50 Denpasar.Umumnya, operator 


\section{gulawentah: Jurnal Studi Sosial}

Volume 2 Nomor 2 Desember 2017 hal 91-101

Avaliable online at http://e-journal.unipma.ac.id/index.php/gulawentah

SPBU dikerjakan oleh para pria.Namun, seiring berkembangnya perubahan zaman kini banyak ditemui para perempuan bekerja sebagai operator SPBU.Ada hal menarik untuk dikaji ketika melihat kenyataan yang tidak sesuai dengan pekerja operator SPBU perempuan pada umumnya.Banyak yang bisa dijumpai ketika operator perempuan SPBU mengenakan pakaian sopan seragam celana panjang dan baju berkerah berwarna merah dengan menggunakan topi bahkan ada yang menggunakan hijab.Di SPBU 54.801.50 Denpasar hal itu tidak diberlakukan, grooming operator perempuan SPBU adalah dengan mengenakan seragam dress mini yang memberi kesan seksi dan menonjolkan tubuh.

Tubuh perempuan memang memiliki banyak makna sehingga banyak para pemegang kepentingan yang memiliki kekuasaan memanfaatkan hal tersebut sebagai daya tarik komoditas. Proses daya tarik yang semula tidak memiliki nilai komoditas hingga menjadi komoditas disebut sebagai komodifikasi. Proses komodifikasi ini merupakan bagian asosiasi terhadap kapitalisme dari objek dan tanda.

Komodifikasi terjadi ketika nilai ekonomi digunakan untuk sesuatu yang sebelumnya tidak dipertimbangkan seperti identitas, jenis kelamin dan ide.Dalam hal ini operator perempuan SPBU berbalut seragam seksi yang tidak sesuai dengan operator SPBU Pada umumnya merupakan penggerak kegiatan produksi dan distribusi.Para kaum kapitalis mempergunakan tubuh dan tenaga mereka secara optimal sebagai bentuk strategi pemasaran dengan tujuan keuntungan perusahaan.Strategi yang ampuh ketika sebuah perusahaan menggunakan daya tarik seksual (utamanya fitur tubuh perempuan) dalam merepresentasikan sebuah produk yang menjadi nilai komoditi. Dari daya tarik tersebut, terbukti telah berpengaruh pada pengembangan sayap SPBU 54.801.50 Denpasar yang kini sudah memiliki berbagai cabang dengan pelayanan daya tarik yang sama. Proses komodifikasi tubuh mendapatkan penerimaan dari para operator perempuan SPBU 54.801.50 Denpasar, strategi pemasaran dengan menggunakan daya tarik tubuh seksi sampai saat ini masih terlihat dinikmati oleh para perempuan penggerak produksi perekonomian.

\section{Kesimpulan}

Berdasarkan dari hasil penelitian dapat disimpulkan bahwa pada SPBU 54.801.50 Denpasar terjadi komodifikasi tubuh pada pekerja operator SPBU perempuan. Komodifkasi tubuh tersebut terjadi akibat pergeseran budaya, gaya hidup dan memudarnya nilai tanda yang akhirnya dijadikan sebagai nilai tukar. Strategi pemasaran yang dilakukan oleh para pemilik kepentingan di perusahaan tersebut dengan memanfaatkan daya tarik sensualitas dari pakaian seksi yang 


\section{gulawentah: Jurnal Studi Sosial}

Volume 2 Nomor 2 Desember 2017 hal 91-101

Avaliable online at http://e-journal.unipma.ac.id/index.php/gulawentah

dikenakan oleh operator perempuan SPBU 54.801.50 Denpasar. Banyak SPBU hadir di Kota Denpasar yang memperkerjakan perempuan sebagai operator, namun adapun perbedaan dari SPBU 54.801.50 adalah dari segi standar operasional grooming penggerak produksi perekonomian disana yang menawarkan tubuh seksi sebagai sebuah daya tarik pembeli.

\section{Daftar Pustaka}

Baudrillard, J. P. (2009). Masyarakat Konsumsi. Yogyakarta : Kreasi Wacana

Basrowi dan Suwandi. (2008). Memahami Penelitian Kualitatif. Jakarta : Rineka Cipta

Bungin, B. (2011). Sosiologi Komunikasi: Teori, Paradigma, dan Diskursus Teknologi Komunikasi di Masyarakat. Jakarta: Kencana

Evan, D.S. \& P. (2004). Das Kapital untuk pemula. Jakarta : Resist Book

Martono, N. (2013). Sosiologi Perubahan Sosial: Perspektif Klasik,Modern, Posmodern, dan Poskolonial. Jakarta: Rajawali Pers

Foucault, M. (2002).Kegilaan dan Peradaban. Yogyakarta: Ikon Teralitera

Piliang, Y. A. (2006). Konsumsi, Selera dan Perubahan Sosial, dalam Adlin, Alfathri. 2006. Menggeledah Hasrat Sebuah Pendekatan Multi Perspektif. Yogyakarta: Jalasutra.
Astuti, S. I. (2005). Komunika :Warta Ilmiah Populer Komunikasi dalam Pembangunan. Jakarta: LIPI

Agung, M. (2013). Kapitalis Media, Jakara: Aura Pustaka

Ritzer, G. (2010). Teori Sosial Postmodern. Yogyakarta: Kreasi Wacana

Silalahi, U. (2010). Metode Penelitian Sosial. Bandung: Refika Aditama : Araska. 